\title{
Repair of a postinfarction ventricular septal defect through the aortic opening - a case report
}

\author{
Łukasz Tułecki ${ }^{1}$, Jeremi Mizerski ${ }^{1,2}$, Jarosław Bródka ${ }^{1}$ \\ ${ }^{1}$ Department of Cardiac Surgery, The John Paul II Regional Hospital, Zamość \\ Interdisciplinary Centre for Mathematical and Computational Modelling, University of Warsaw, Warsaw
}

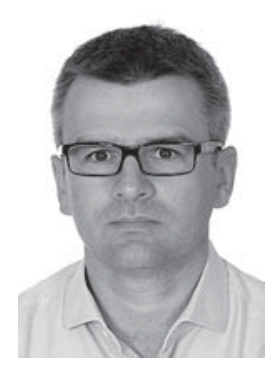

Kardiochirurgia i Torakochirurgia Polska 2013; 10 (2): 154-157

\begin{abstract}
Repairing postinfarction ventricular septal defects located in the posterobasal part of the septum is one of the most demanding procedures in cardiac surgery. In the presented case of a 63-year-old patient, an approach through the aortic valve opening was applied. The method was adopted from the field of congenital heart surgery. The presented technique may be a good alternative to the widely used approach employing posterior ventriculotomy.

Key words: postinfarction ventricular septal defect, mechanical complications, myocardial infarction.
\end{abstract}

\section{Introduction}

In spite of constant progress in medical technology, postinfarction ventricular septal defects (VSDs) still pose a challenge for the cardiac surgeon. Introducing various new methods of early reperfusion of the heart area affected by the infarction (such as thrombolysis or percutaneous coronary procedures) allowed for the reduction of the incidence of this life-threatening complication: from $1-2 \%$ to $0.2 \%$ of acute myocardial infarctions [1, 2]. Although cardiac surgeons have several techniques for repairing postinfarction VSDs at their disposal, mortality for these procedures is still high (20-50\%) and remains unsatisfactory $[3,4]$. The method which is currently used most often is the method introduced by David [5]: it employs an endocardial patch to repair the defect and protect the fragment of the ventricular septum weakened by ischemia (an exclusion technique). Many modifications have been introduced to this procedure; however, it always requires ventriculotomy, which consequently causes further damage to the infarcted regions of the heart. The technique of repairing posterior postinfarction VSDs through the aortic opening presented in this article originated in the field of congenital heart defect surgery, and it enables the surgeons to avoid incising the muscles of the cardiac ventricles [6]. As surgi-

\section{Streszczenie}

Operacja pozawałowego ubytku w przegrodzie międzykomorowej umiejscowionego w tylno-przypodstawnej części przegrody należy do najbardziej wymagających zabiegów kardiochirurgicznych. W prezentowanym przypadku 63-letniego chorego zastosowano technikę dostępu przez ujście aortalne, zaadaptowaną z chirurgii wad wrodzonych serca. Opisana metoda może być korzystną dla pacjenta alternatywą w stosunku do klasycznego dostępu przez tylną wentrikulotomię.

Słowa kluczowe: pozawałowy ubytek w przegrodzie międzykomorowej, mechaniczne powikłania zawału serca, zawał serca.

cal tools for minimally invasive techniques are now widely available, the benefits that the transaortic access offers to the patient appear to be encouraging.

\section{Case study}

A 63-year-old patient was admitted to the hospital due to squeezing and burning chest pains that had persisted for several days. The conducted diagnostics revealed an ST-segment elevation myocardial infarction (STEMI) of the inferior wall. Coronarographic examination was performed immediately, revealing three-vessel coronary artery disease. It was followed by an uneventful angioplasty of the right coronary artery in the distal segment, which included the implantation of two bare-metal stents. After the procedure the patient felt well and his rehabilitation began, in accordance with the binding standards. During the 14th day after the infarction, the patient felt sudden dyspnea and discomfort in the chest. Auscultative examination revealed a new loud murmur over the whole heart. Echocardiography revealed a postinfarction defect in the posterobasal part of the ventricular septum with a significant left-to-right shunt. Immediately after the implementation of an intra-aortic balloon pump (IABP) the patient lost consciousness; he was intubated and moved to

Address for correspondence: Łukasz Tułecki, Department of Cardiac Surgery, The John Paul II Regional Hospital in Zamość, Poland, tel. +48 601997 403, e-mail: luke27@poczta.onet.pl 
a cardiac intensive care room. Thanks to the assistance of the IABP and the inclusion of catecholamines and diuretics, hemodynamic stability was attained; however, due to unclear neurological status (the patient was unconscious and was not reacting to stimuli) emergency cardiac surgery was not undertaken. During the subsequent days, imaging examination excluded the possibility of severe brain damage, and the patient's neurological status improved gradually - the patient regained consciousness and started to react to stimuli; periodically he appeared to comply with simple instructions. During the $8^{\text {th }}$ day after the diagnosis of post-myocardial infarction VSD, the patient was moved to the operating room for surgical treatment (Fig. 1).

The chest was opened by median sternotomy. Standard cannulation of both venae cavae and the ascending aorta was performed. After the heart was stopped, the aorta was incised transversally c. $1.5 \mathrm{~cm}$ above the right coronary ar-

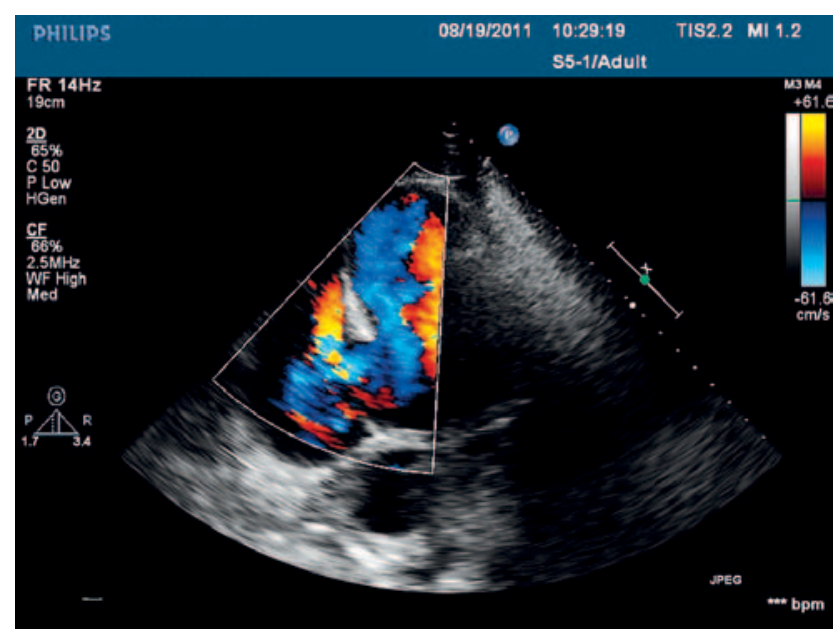

Fig. 1. Preoperative condition - a large postinfarction defect in the posterior part of the ventricular septum revealed by transesophageal echocardiography

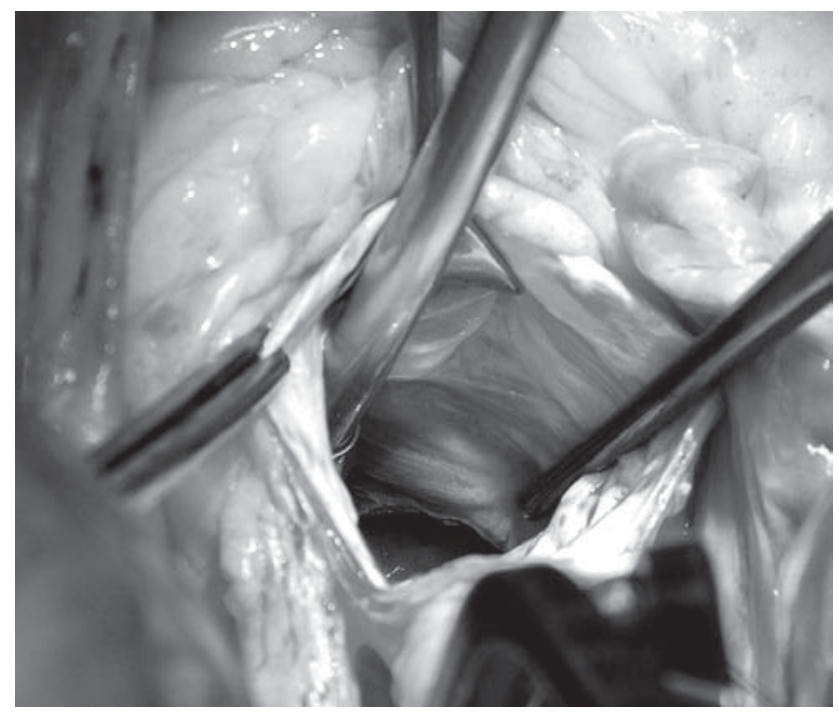

Fig. 2. Intraoperative view - the defect in the ventricular septum observed through the aortic opening tery opening. A significant postinfarction defect in the posterobasal part of the ventricular septum was made visible through the aortic opening (the diameter of the aortic annulus was $23 \mathrm{~mm}$ according to the preoperative ECG). The defect was bordered by necrotic, fragile tissue of the cardiac muscle. By maneuvering the surgical sponge inserted below the lower wall of the heart, the ventricular septum was pushed slightly forward, which allowed for a very good view of the whole circumference of the defect (Fig. 2).

Subsequently, singular 4-0 sutures with Teflon patches were inserted with minimally invasive tools over the whole circumference of the defect; the patches were implemented from the side of the right ventricle, within the boundaries of healthy tissue. The VSD was closed with a cut-to-size synthetic polyester patch (Bard ${ }^{\circledR}$ Sauvage ${ }^{\circledR}$, made in the USA); both the rupture and the necrotic tissue were covered from the side of the left ventricle. Both during the suturing and the patching, the structural elements of the mitral valve were carefully monitored, so as not to damage them or to insert the sutures between the tendinous cords (Fig. 3).

The aortotomy was then closed in a standard fashion; additionally, a bypass of the left internal thoracic artery (LITA) was made to the left anterior descending (LAD) branch of the left coronary artery due to a significant constriction in the proximal segment of the vessel. Extracorporeal circulation was turned off without complications thanks to the assistance of intra-aortic counterpulsation and low doses of catecholamines. The patient did not require external heart stimulation. Transesophageal echocardiography (TEE) revealed that the synthetic patch covered the postinfarction VSD tightly; there were no signs of leakage, and the functioning of the aortic and mitral valves was normal.

Postoperatively, the patient required prolonged mechanical ventilation due to the unclear neurological status - he was extubated during the $5^{\text {th }}$ postoperative day. No neurological defects were revealed. Immediately after re-

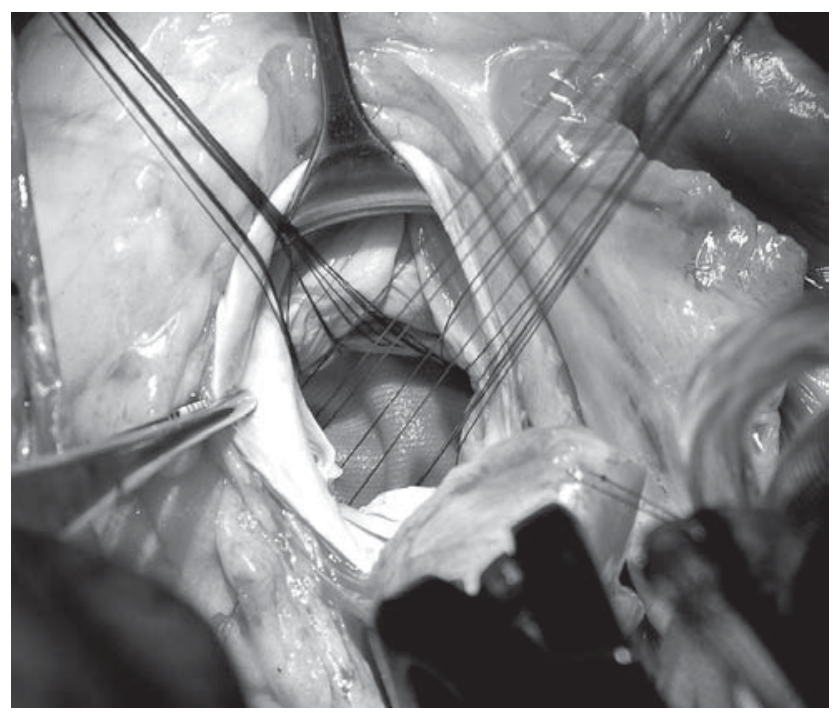

Fig. 3. Intraoperative view - a synthetic patch was introduced inside the left ventricle in order to cover the defect 
moving the IABP, revision of the right femoral artery was performed due to signs of right lower extremity ischemia. Subsequent postoperative progress was uneventful. The follow-up echocardiographic examination performed 7 months after the operation did not reveal any pathological leakage through the ventricular septum; it confirmed the proper functioning of the aortic valve and a slight insufficiency of the mitral valve. An out-patient checkup performed 14 months after the surgery showed that the patient was in good condition, exhibited circulatory and respiratory sufficiency, and did not have any cardiac complaints (Fig. 4).

\section{Discussion}

Approximately $40 \%$ of postinfarction defects in the ventricular septum occur in the posterobasal part of the septum (so-called posterior VSD). Most frequently, it is a result of an infarction related to the occlusion of the right coronary artery (RCA). Due to its location, the posterior VSD is much more difficult to access surgically than the socalled anterior VSD located in the anterior part of the septum. Technical difficulties are the most probable cause of the slightly higher mortality among patients with posterior VSD, as compared to anterior VSD; therefore the search for new solutions in treating this life-threatening postinfarction complication is ongoing [4].

Posterior postinfarction VSDs are located in the vicinity of the mitral valve complex (posteromedial papillary muscle, tendinous cords), which significantly impedes (if not prevents) the closure of such defects using the ever-developing percutaneous techniques. Moreover, its diameter typically exceeds $15 \mathrm{~mm}$, which is the largest defect diameter that should be closed with minimally invasive methods according to the current guidelines [7].

The method of closing a postinfarction posterior VSD through an aortic opening presented in this paper possesses, in the opinion of the authors, certain advantages in comparison to traditional classical methods [8]. Most importantly, incising the cardiac ventricular muscle (infarctectomy) is avoided, as the muscle is typically already damaged by the extensive infarction. The ventricular walls remain untouched, which may prevent postoperative low cardiac output syndrome. Another advantage is the relatively easy control of hemostasis - the only line of stitching is related to the aorta; it is well visible and easy to repair. As the use of dual antiplatelet therapies and other anticoagulants is becoming more widespread, it is a significant advantage not to have to suture the wall of the left ventricle in the area of the ischemia. Perhaps the presented method may reduce the amount of transfused blood and bloodbased products after VSD treatments; there are, however, no data to confirm this. In the three cases of employing the transaortic method that we observed, there was little postoperative drainage, and therefore the need for bloodbased products was markedly lower.

While operating through the aortic opening, administering cardioplegia directly to the coronary openings does

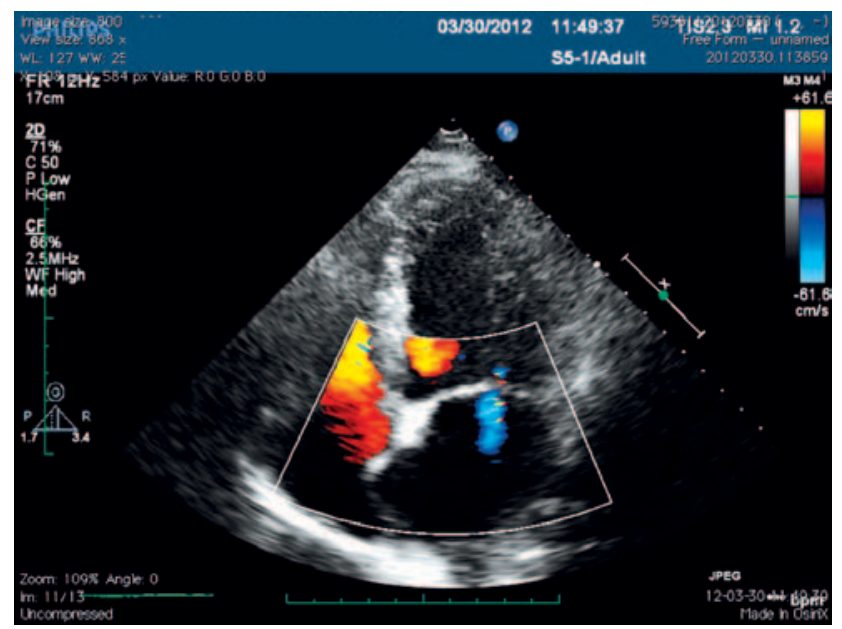

Fig. 4. Transthoracic echocardiography 7 months after the surgery - the tightly closed ventricular septum and a slight insufficiency of the mitral valve can be observed

not pose any problems - it is quick and reliable. This allows one to save several minutes, which is important in operations as long as this one. Retrograde administration of cardioplegia, preferred by some, is also possible; however, blood flowing out of the coronary openings may limit visibility in the operating field. In the presented case, cold blood cardioplegia was administered directly into the coronary openings every 20-30 minutes.

Another aspect is the good visibility of the defect. In order to obtain access to a posterior VSD, classical methods require a significant dislocation of the heart so as to perform infarctectomy on the posterior wall. Furthermore, locating the defect is often time consuming, as is determining the exact anatomy of the VSD's vicinity. Tissue stress occurring during the dislocation of the heart impedes the suturing of the endocardial patch and may lead to further damage. By employing a few simple maneuvers (the abovementioned sponge under the lower wall of the heart, an atraumatic retractor on the aortic wall) the presented method of obtaining access through an aortic opening allows for very good and quick exposure of the defect. This in turn enables the exact evaluation of the boundaries of the VSD and the quality of its constituent tissues, as well as the precise determination of the anatomy of the neighboring structures. It is almost an in situ visualization, without tissue stress and without deformation resulting from the dislocation of the heart (as opposed to the classical methods). However, appropriate equipment is required for conducting such an operation - minimally invasive equipment popularly used in mitral valve mini-access surgery as well as an individual light source fastened to the head of the surgeon. The ability to maneuver through the narrow (2-3 cm in width) aortic opening is significantly limited in the case of classical tools; therefore, only minimally invasive equipment enables the precise repair of the defect with this method. Exercising basic caution should prevent any damage to the aortic valve. Normal aortic cusps stick 
to the wall of the aortic bulb and do not impede access to the inside of the left ventricle. In the case of cusps with primary pathological lesions, or if the cusps are damaged during the surgery, there is always the option of removing them and inserting an artificial valve during the final stage of the procedure. Both in the case presented above and in two other cases handled by our medical center, the aortic valve was not damaged during the surgery and its functioning was demonstrated to have been the same as before the surgery by postoperative TEE.

\section{Conclusions}

The presented method for transaortic repair of posterior VSD follows the current trend of minimizing the invasiveness of cardiac surgery. The primary aim of using this approach was, however, to avoid posterior ventriculotomy and attain the best possible visibility. Based on as yet limited experience ( 3 cases), it can be postulated that transaortic access is safe, is possible to perform in a relatively short time frame, and allows for the significant reduction of interference with the myocardium of the left ventricle, already damaged by the disease. In our opinion, this technique can be a good alternative to traditional posterior ventriculotomy in the case of posterior VSD.

\section{References}

1. Pohjola-Sintonen S, Muller JE, Stone PH, Willich SN, Antman EM, Davis VG, Parker CB, Braunwald E. Ventricular septal and free wall rupture complicating acute myocardial infarction: experience in the Multicenter Investigation of Limitation of Infarct Size. Am Heart J 1989; 117: 809-818.

2. Crenshaw BS, Granger CB, Birnbaum Y, Pieper KS, Morris DC, Kleiman NS, Vahanian A, Califf RM, Topol EJ. Risk factors, angiographic patterns and outcomes in patients with ventricular septal defect complicating acute myocardial infarction. Circulation 2000; 101: 27-32.

3. Deja MA, Szostek J, Widenka K, Szafron B, Spyt TJ, Hickey MS, Sosnowski AW. Post infarction ventricular septal defect - can we do better? Eur J Cardiothorac Surg 2000; 18: 194-201.

4. Coskun KO, Coskun ST, Popov AF, Hinz J, Schmitto JD, Bockhorst K, Stich $K M$, Koerfer R. Experiences with surgical treatment of ventricle septal defect as a post infarction complication. J Cardiothorac Surg 2009; 4: 3.

5. David TE. Operative management of postinfarction ventricular septal defect. Semin Thorac cardiovasc Surg 1995; 7: 208-213.

6. Leao LE, Buffolo E, Coto AE, Maluf MA, Andrade JC. Transaortic approach has a role in the surgical treatment of ventricular septal defects. Cardiovasc Surg 1996; 4: 250-254.

7. Maltais S, Ibrahim R, Basmadjian AJ, Carrier M, Bouchard D, Cartier R, Demers P, Ladouceur M, Pellerin M, Perrault LP. Postinfarction ventricular septal defects: Towards a new treatment algorithm? Ann Thorac Surg 2009; 87: 687-693.

8. Vlessis AA, Hanlon T. Repair of acute postinfarction ventricular septal defect by endocardial patch exclusion through the aortic valve orifice. J Thorac Cardiovasc Surg 2005; 129: 223-224. 